\title{
Analisis Sistem Pengendalian Intern Piutang Dalam Meminimalisir Piutang Tak Tertagih Pada PT. Cakrawala Multi Finance Palembang
}

\author{
Santi Puspita \\ Manajemen, Fakultas Ekonomi Universitas PGRI Palembang, \\ Email : santipuspita@univpgri-palembang.ac.id
}

\begin{abstract}
ABSTRAK
Tujuan yang ingin dicapai dalam penelitian ini adalah untuk mengetahui apakah sistem pengendalian intern piutang dilaksanakan PT. Cakrawala Multi Finance Palembang dalam meminimalisir piutang tak tertagih. Variabel bebas di dalam penelitian ini adalah pengendalian intern piutang dan variabel terikatnya adalah piutang tak tertagih. Populasi penelitian ini adalah daftar piutang dan piutang tak tertagih pada PT. Cakrawala Multi Finance Palembang dan sampelnya adalah daftar piutang dan piutang tak tertagih pada PT. Cakrawala Multi Finance Palembang dari tahun 2015-2017. Metode penelitian yang digunakan adalah penelitian deskriftif. Data yang digunakan adalah data sekunder. Teknik analisis data yang digunakan adalah analisis kualitatif. Hasil Penelitian menunjukkan bahwa kredit bermasalah dari tahun 2015, 2016, dan 2017 sebesar 50, 38\%, 53,83\%, 56,83\% itu bertanda perusahaan masih memiliki kekurangan jika dinilai dari keempat unsur pengendalian intern (Struktur organisasi yang memisahkan tanggung jawab fungsional secara tegas, sistem wewenang dan prosedur pencatatan yang memberikan perlindungan yang cukup terhadap kekayaan, utang, pendapatan, dan biaya, praktik yang sehat dalam melaksanakan tugas dan fungsi setiap unit organisasi, karyawan yang mutunya sesuai dengan tanggung jawab).
\end{abstract}

Kata Kunci: Pengendalian Intern Piutang dalam Meminimalisir Piutang Tak Tertagih

\section{A. Pendahuluan}

Salah satu aspek penting pada suatu perusahaan adalah sistem pengendalian intern. Karena suatu perusahaan tidak dapat berjalan dengan baik tanpa adanya sistem pengendalian intern yang baik. Menurut Mulyadi (2002:163), adapun tujuan dari sistem pengendalian intern adalah untuk menjaga kekayaan organisasi, mengecek ketelitian dan keandalan data akuntansi, mendorong efisiensi serta mendorong dipatuhinya kebijakan manajemen. Dilihat dari tujuan tersebut maka, sistem pengendalian intern dapat dibagi menjadi dua, pengendalian intern akuntansi dan pengendalian administrasi. Pengendalian intern akuntansi dibuat untuk menjaga kekayaan perusahaan dan memeriksa keakuratan data akuntansi. Pengendalian administrasi dibuat untuk mendorong dilakukannya efisiensi dan mendorong dipatuhinya kebijakan manajemen.

Menurut Mulyadi (2002:165), dalam sistem pengendalian intern terdapat beberapa sistem akuntansi yang meliputi sistem akuntansi penjualan, sistem akuntansi piutang, sistem akuntansi pembelian, sistem akuntansi utang, sistem penggajian dan pengupahan, sistem akuntansi biaya, sistem penerimaan kas, sistem pengeluaran kas, sistem akuntansi persediaan dan sistem akuntansi aktiva tetap.

Menurut Mulyadi (2002:205) Piutang merupakan salah satu aktiva yang bersifat likuid, dan seperti kita ketahui bahwa piutang merupakan kas yang tertunda penerimaannya yang ditentukan oleh waktu. Ada semacam resiko yang mungkin akan terjadi yaitu 
tidak tertagihnya piutang tepat pada waktunya atau bahkan kerugian akibat konsumen gagal bayar.

Piutang merupakan elemen modal kerja yang selalu dalam keadaan berputar secara terus menerus dalam rantai perputaran modal kerja yaitu kas, persediaan, piutang. Dalam keadaan normal dan dimana penjualan pada umumnya dilakukan dengan kredit. Piutang mempunyai tingkat likuiditas yang lebih tinggi dari pada persediaan, karena perputaran dari piutang ke kas membutuhkan satu langkah, yang penting kebijaksanaan kredit yang efektif dan prosedur-prosedur penagihan untuk menjamin penagihan piutang yang tepat pada waktunya dan mengurangi kerugian akibat piutang tak tertagih.

Menurut Kasmir (2011:109-110) Untuk itu perlu kiranya perusahaan menerapkan sistem 5C (character, capacity, collateral, condition, dan capital) sebelum kredit diberikan kepada konsumen, selain itu perusahaan juga perlu melakukan penilaian terhadap piutang contohnya: melalui analisis umur piutang.

PT. Cakrawala Multi Finance Palembang bergerak dalam penjualan jasa di bidang pembiayaan kredit elektronik. Kegiatan utama PT. Cakrawala Multi Finance Palembang adalah melakukan pembiayaan yang sebagian besar pembiayaan tersebut dilakukan secara kredit.

Fenomena masalah yang terjadi di PT. Cakrawala Multi Finance Palembang adalah terjadinya tunggakan macet / kredit macet, dan perangkapan antara fungsi keuangan dan fungsi administrasi yang dapat menimbulkan kemungkinan terjadinya pencatatan transaksi yang sebenarnya tidak terjadi, sehingga data akuntansi yang dihasilkan tidak dapat dipercaya kebenarannya, dan sebagai akibatnya kekayaan organisasi tidak terjamin keamanannya. Dari perangkapan fungsi tersebut maka perusahaan mengalami penurunan laba. Adapun data piutang yang tak tertagih terlihat pada tabel dibawah ini :

Tabel 1

Daftar Piutang Pembiayaan dan Piutang Tak Tertagih

\begin{tabular}{|l|l|l|l|l|}
\hline \multicolumn{1}{|c|}{ Tahun } & $\begin{array}{c}\text { Jumlah } \\
\text { Pembiayaan(Rp) }\end{array}$ & $\begin{array}{c}\text { Piutang } \\
\text { Pembiayaan(Rp) }\end{array}$ & $\begin{array}{c}\text { Piutang Tak } \\
\text { Tertagih(Rp) }\end{array}$ & $\begin{array}{c}\text { Kredit } \\
\text { Bermasalah }\end{array}$ \\
\hline 2015 & 4.210 .000 .000 & 3.963 .000 .000 & 247.500 .000 & $5,8 \%$ \\
\hline 2016 & 7.070 .000 .000 & 6.502 .000 .000 & 568.000 .000 & $8,03 \%$ \\
\hline 2017 & 7.326 .000 .000 & 6.870 .000 .000 & 456.000 .000 & $6,2 \%$ \\
\hline
\end{tabular}

Sumber : PT. Cakrawala Multi Finance Palembang, 2013

Dari tabel diatas dapat dilihat terjadinya peningkatan dalam piutang tak tertagih dari tahun ke tahun. Adapun persentase yang tertinggi pada tahun 2012 yaitu $8,03 \%$. Maka dari itu perusahaan perlu melakukan pengendalian intern piutang agar dapat meminimalisir piutang tak tertagih dan mencapai tujuannya secara maksimal.

\section{B. Rumusan Masalah}

Berdasarkan latar belakang maka rumusan masalah dalam penelitian ini adalah "Bagaimana sistem pengendalian intern piutang dalam meminimalisir piutang tak tertagih pada PT. Cakrawala Multi Finance Palembang?"

\section{Metode Penelitian}

Menurut Sugiyono (2012:29), metode deskriftif adalah metode yang 
digunakan untuk menggambarkan atau menganalisis suatu hasil penelitian tetapi tidak digunakan untuk membuat kesimpulan yang lebih luas.

\section{Populasi dan Sampel}

Menurut Sugiyono (2012:215), populasi adalah wilayah generalisasi yang terdiri dari objek atau subjek yang mempunyai kualitas dan karakteristik tertentu yang ditetapkan oleh peneliti untuk dipelajari dan kemudian ditarik kesimpulannya. Populasi dari penelitian ini adalah daftar piutang dan piutang tak tertagih pada PT. Cakrawala Multi Finance Palembang.

Menurut Sugiyono (2012:117), Sampel adalah bagian dari jumlah dan karakteristik dari populasi yang diteliti. Sampel dari penelitian ini adalah daftar piutang tak tertagih pada PT. Cakrawala Multi Finance Palembang dari Tahun 2015-2017.

\section{E. Teknik Pengumpulan Data}

Menurut Anwar (2011:105-114) menyatakan ada beberapa cara dalam pengumpulan data yaitu :

1. Observasi, merupakan cara pengumpulan data melalui proses pencatatan perilaku subjek (orang), objek (benda) atau kejadian yang sistematik tanpa adanya pertanyaan atau komunikasi dengan individuindividu yang diteliti.

2. Survei, cara survei merupakan cara pengumpulan data dimana peneliti atau pengumpul data mengajukan pertanyaan atau pernyataan kepada responden baik dalam bentuk lisan maupun secara tertulis.

3. Wawancara, wawancara merupakan teknik pengumpulan data yang menggunakan pertanyaan secara lisan kepada subjek penelitian.
4. Kuesioner, kuesioner merupakan pengumpulan data dengan cara memberikan daftar pertanyaan kepada responden untuk diisi.

5. Dokumentasi, cara dokumentasi biasanya dilakukan untuk mengumpulkan data sekunder dari berbagai sumber, baik secara pribadi maupun kelembagaan.

Teknik pengumpulan data yang akan digunakan dalam penelitian yang akan dilakukan adalah pengumpulan data dokumentasi dan data-data lain yang diperlukan yang didapat dari perusahaan.

\section{F. Teknik Analisis Data}

Menurut Mudrajad (2003 : 145) metode analisis terdiri dari :

a. Analisis kuantitatif

Analisis kuantitatif adalah suatu metode analisis data yang diukur dalam suatu skala numerik (angka).

b. Analisis Kualitatif

Analisis kualitatif adalah suatu metode analisis data yang diukur dengan cara memberikan penjelasan dalam bentuk katakata atau dalam bentuk kalimat.

Analisis data yang akan digunakan dalam penelitian yang akan dilakukan adalah analisis kualitatif, yaitu dengan menjelaskan atau menguraikan dengan menggunakan teori-teori yang berkaitan dengan objek penelitian.

\section{G. Hasil Penelitian}

1) Prosedur Penjualan dan Kebijaksanaan Pemberian Kredit pada PT. Cakrawala Multi Finance Palembang

Dalam melaksanakan aktivitas penjualan, PT. Cakrawala Multi Finance Palembang bekerjasama dengan toko (store) dan agen-agen penjualan elektronik. Bentuk kerjasama yang dijalin yaitu pihak toko (store) 
akan menyediakan unit elektronik untuk setiap calon konsumen yang ingin memperoleh kredit kepemilikan elektronik.

PT. Cakrawala Multi Finance Palembang menyebarkan brosur daftar harga ke setiap toko dan agen elektronik yang telah di ajak bekerja sama. Jika konsumen ingin membeli secara kredit, dalam brosur tersebut telah disebutkan tipe elektronik, harga elektronik, jangka waktu kredit, uang muka yang harus disetor, dan angsuran per bulan yang harus dibayar. Setelah konsumen menentukan pilihannya untuk membeli secara kredit, maka pihak toko atau agen akan segera menghubungi customer service PT. Cakrawala Multi Finance Palembang agar segera dikirim surveyor untuk melakukan survey terhadap calon konsumen. Dalam hal ini customer service mempunyai wewenang untuk memilih surveyor mana yang akan melakukan survey.

Kemudian surveyor yang telah mendapat tugas akan segera mendatangi toko atau rumah konsumen tersebut untuk memastikan tempat tinggalnya dengan meminta konsumen untuk menyediakan datadata seperti fotocopy KTP yang masih berlaku, fotocopy Kartu Keluarga, fotocopy slip gaji bagi pegawai dan fotocopy rekening listrik atau air.

Tugas utama surveyor dalam hal ini adalah mencari data-data yang akurat mengenai konsumen untuk dapat memastikan apakah konsumen tersebut layak diberi kredit atau tidak. Seluruh data yang diperlukan sebagai bahan pertimbangan harus dicantumkan dalam formulir pengajuan kredit. Setelah itu surveyor akan membawa formulir pengajuan kredit tersebut beserta kelengkapan data kepada komite kredit yang terdiri dari marketing head, dan kepala operasi yang diberi wewenang untuk memutuskan apakah konsumen tersebut layak diberi kredit. Bila tidak terdapat kata sepakat dari komite kredit maka keputusan layak atau tidak ditentukan oleh Kepala Cabang.

Untuk setiap pengajuan kredit yang sudah disetujui maka customer service membuat surat order pembelian ke toko yang intinya permintaan pengiriman unit elektronik dengan spesifikasi tertentu ke alamat konsumen.

Dan untuk calon konsumen yang langsung datang ke PT. Cakrawala Multi Finance Palembang akan dilayani oleh customer service dan diperlakukan sama dengan calon konsumen yang datang ke toko.

Dalam menghadapi persaingan dari perusahaan pembiayaan lain, pihak manajemen menetapkan kebijaksanaan pemberian kredit yang ringan. Untuk jangka waktu kredit, konsumen ditawarkan untuk membayar angsuran mulai dari 1 (satu) tahun sampai dengan 5 (lima) tahun. Dan untuk setiap pengajuan kredit yang disetujui maka calon konsumen harus membayar uang muka 10\% dari harga unit elektronik.

Untuk konsumen perorangan hanya diperbolehkan memperoleh pembiayaan kredit sebanyak 1 unit. Dan boleh mengajukan pembiayaan untuk unit yang lain berdasarkan catatan pembayaran angsurannya setelah berjalan minimal 6 (enam) bulan. Khusus untuk konsumen perusahaan, PT. Cakrawala Multi Finance Palembang membatasi maksimal 5 (lima) unit sekali pengajuan kredit dan harus disertai dengan jaminan kepastian pembayaran seperti pembayaran dengan giro atau debet rekening perusahaan.

Calon konsumen yang akan diberi kredit adalah konsumen yang dinilai mempunyai penghasilan tetap, dan PT. 
Cakrawala Multi Finance Palembang berusaha untuk memperoleh jaminan dari calon konsumen. Tetapi kebijaksanaan ini tidak berlaku mutlak.
2) Data Piutang dan Piutang Tak Tertagih pada PT. Cakrawala Multi Finance Palembang

Tabel 2

Daftar Piutang Pembiayaan dan Piutang Tak Tertagih

\begin{tabular}{|c|c|c|c|c|}
\hline Tahun & $\begin{array}{c}\text { Jumlah } \\
\text { Pembiayaan(Rp) }\end{array}$ & $\begin{array}{c}\text { Piutang } \\
\text { Pembiayaan(Rp) }\end{array}$ & $\begin{array}{c}\text { Piutang Tak } \\
\text { Tertagih(Rp) }\end{array}$ & $\begin{array}{c}\text { Kredit } \\
\text { Bermasalah }\end{array}$ \\
\hline 2015 & 4.210 .000 .000 & 3.963 .000 .000 & 247.500 .000 & $5,8 \%$ \\
\hline 2016 & 7.070 .000 .000 & 6.502 .000 .000 & 568.000 .000 & $8,03 \%$ \\
\hline 2017 & 7.326 .000 .000 & 6.870 .000 .000 & 456.000 .000 & $6,2 \%$ \\
\hline
\end{tabular} Sumber : PT. Cakrawala Multi Finance Palembang, 2013

Berdasarkan data di atas, dapat dilihat bahwa jumlah pembiayaan atau penjualan secara kredit tiap tahunnya terus meningkat. Namun kenaikan pembiayaan ini selalu diikuti oleh kenaikan piutang tak tertagih. Jumlah pembiayaan pada akhir periode 2015 sebanyak Rp 4.210.000.000 dan piutang pembiayaan $\mathrm{Rp} 3.963 .000 .000$ sedang piutang yang dianggap tidak dapat ditagih karena sudah melampaui tanggal jatuh tempo penjualan $R p$ 247.500.000. Pada akhir 2016 jumlah pembiayaan meningkat sebesar $R p$ 7.070.000.000 dan piutang pembiayaan $\mathrm{Rp}$ 6.502.000.000 sedang piutang yang dianggap tidak dapat ditagih karena sudah melampaui tanggal jatuh tempo penjualan Rp 568.000.000. Dan pada akhir 2017 jumlah pembiayaan meningkat sebesar Rp 7.326.000.000 dan piutang pembiayaan $\mathrm{Rp}$ 6.870.000.000 sedang piutang yang dianggap tidak dapat ditagih karena sudah melampaui tanggal jatuh tempo penjualan $R p$ 456.000.000.

Secara matematis persentase piutang tak tertagih / kredit bermasalah dapat dihitung:

$\%$ Piutang Tak Tertagih $=\frac{\text { Piutang tak tertagih }}{\text { Jumlah Pembiayaan }} \times 100 \%$

Rp 247.500.000

Piutang tak tertagih tahun $2015=\frac{\operatorname{Rp} 4.210 .000 .000}{}$

$X 100 \%=5,8 \%$

Rp 568.000.000

Piutang tak tertagih tahun 2016

$X 100 \%=8,03 \%$

Rp 7.070.000.000

Rp 456.000.000

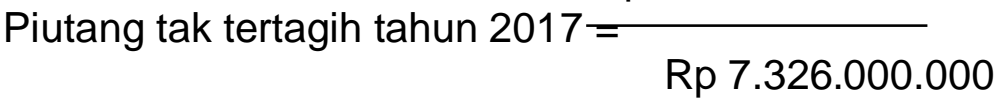

$X 100 \%=6,2 \%$

Berdasarkan perhitungan tersebut pada tahun 2015 persentase piutang tak tertagih sebesar 5,8\%. Dan pada tahun 2016 persentase piutang tak tertagih sebesar $8,03 \%$. Sedangkan 
pada tahun 2017 persentase piutang tak tertagih sebesar 6,2\%.

\section{H. Pembahasan}

1) Analisis Prosedur Penjualan Kredit pada PT. Cakrawala Multi Finance Palembang

Prosedur penjualan kredit pada perusahaan ini telah dilaksanakan dengan baik. Adanya customer service yang menangani semua permintaan kredit menunjukkan adanya prosedur order penjualan. Untuk semua permohonan kredit, customer service telah menentukan surveyor untuk melakukan survey tentang kelayakan calon konsumen. Setelah surveyor melengkapi data calon konsumen maka akan dilanjutkan dengan persetujuan kredit. Dalam prosedur persetujuan kredit ini perusahaan telah membentuk sebuah komite kredit yang berwenang untuk menentukan layak atau tidaknya calon konsumen diberi kredit. Kriteria utama untuk disetujui permohonan kredit bahwa pemohon memiliki sumber penghasilan yang tetap, dan bila konsumen akan pindah maka harus memberitahukannya kepada pihak perusahaan.

Prosedur penagihan dilakukan oleh departemen piutang dan pelaksana penagihan dilakukan oleh kolektor. Dalam prosedur ini terkait fungsi penerimaan uang kas oleh kasir. Setiap uang penagihan diterima oleh kasir dan setiap harinya akan disetor oleh bank.

Dalam prosedur pencatatan piutang melibatkan departemen kredit dan departemen akuntansi. Suatu piutang akan otomatis muncul bila departemen kredit telah memasukkan data kredit yang telah disetujui dan transaksi pencatatan diotorisasi oleh credit analist. Dan untuk proses selanjutnya yaitu penerimaan kas dilaksanakan oleh bagian akuntansi.
Uraian diatas menunjukkan bahwa prosedur order penjualan, prosedur persetujuan kredit, prosedur pengiriman, prosedur pengiriman, prosedur pencatatan piutang dan prosedur distribusi penjualan telah dimiliki dan dijalankan oleh PT. Cakrawala Multi Finance Palembang dalam praktek penjualan kredit mereka.

\section{2) Analisis Unsur Sistem Pengendalian Intern Piutang PT. Cakrawala Multi Finance Palembang \\ PT. Cakrawala Multi Finance} Palembang sebagai perusahaan yang bergerak dalam bidang pembiayaan konsumen mempunyai peranan penting kepada masyarakat yang ingin mempunyai elektronik baru dengan cara kredit. Maka dari itu perusahaan tetap melakukan pengendalian agar kegiatan perusahaan dapat berjalan dengan efektif dan aman dari tindakantindakan penyelewengan.

Unsur pengendalian intern piutang yang diterapkan oleh PT. Cakrawala Multi Finance Palembang seperti yang telah dikemukakan sebelumnya dalam unsur pokok yang harus ada jika dikehendaki sistem pengendalian intern dalam suatu perusahaan agar sesuai dengan rencana yang telah dibuat untuk mencapai laba perusahaan.

Adapun unsur-unsur sistem pengendalian intern tersebut mencakup

Struktur organisasi yang
memisahkan tanggung jawab
fungsional secara tegas.
Dalam pembahasan ini peneliti menggunakan teori-teori yang dapat di pergunakan dalam permasalahan yang terjadi pada perusahaan PT. Cakrawala Multi Finance Palembang. Untuk itu teori-teori yang digunakan dalam pembahasan ini dapat dipakai 
sebagai analisis terhadap permasalahan yang terjadi.

Aktivitas yang ada pada PT. Cakrawala Multi Finance Palembang dimana merupakan perusahaan yang bergerak dibidang pembiayaan elektronik untuk semua jenis merk elektronik. Pelanggan terlebih dahulu menghubungi tim marketing untuk membuat janji pengajuan permohonan pembiayaan. Menyerahkan syaratsyarat dan mengisi formulir permohonan pembiayaan untuk memudahkan petugas marketing mengetahui identitas pelanggan. Mengarahkan kepada pelanggan pada struktur kredit yang baik bagi perusahaan dan calon pelanggan. Menyiapkan kelengkapan dokumendokumen dan data-data yang dibutuhkan untuk melakukan survey. Dari staff marketing kemudian dilanjutkan ke bagian administrasi yang bertanggung jawab dalam penyimpanan dan pemeliharaan semua dokumen dalam map perjanjian kredit dengan tetap mempertahankan kelengkapan dan kerapian dokumen tersebut.

Perusahaan PT. Cakrawala Multi Finance Palembang, perangkapan tugas terjadi antara fungsi administrasi dan keuangan (teller) dengan staff finance. Hal ini yang menyebabkan terjadinya kesalahan pencatatan transaksi cash dan non cash dari staff accounting (teller). Hal ini dikarenakan pihak yang mengatur jalannya keuangan di perusahaan di atur oleh orang yang sama.

Untuk mengatasi permasalahan yang terjadi, fungsi administrasi, keuangan (teller) dan staff finance harus di pisah untuk mengurangi terjadinya kesalahan dalam pencatatan transaksi cash maupun non cash. Selain itu tugas penerimaan dan pengeluaran keuangan juga harus diterapkan untuk menghindari terjadinya kecurangan dan kesalahan pencatatan transaksi cash maupun non cash dan kekayaan organisasi terjamin keamannya.

b) Sistem wewenang dan prosedur pencatatan yang memberikan perlindungan yang cukup terhadap kekayaan, utang, pendapatan, dan biaya.

Dalam organisasi, setiap transaksi hanya terjadi atas dasar otorisasi dari pejabat yang memiliki wewenang untuk menyetujui terjadinya transaksi tersebut. Oleh karena itu, dalam organisasi harus dibuat sistem yang mengatur pembagian wewenang untuk otorisasi atas terlaksananya setiap transaksi. Sistem wewenang dan prosedur pencatatan piutang ini terjadi atas dasar otorisasi dari pejabat yang memiliki wewenang untuk menyetujui terjadinya transaksi tersebut. Oleh karena itu dalam organisasi harus dibuat tugas dan tanggung jawab sehingga memudahkan pelimpahan wewenang dan fungsi yang bertanggung jawab atas tugasnya. Formulir merupakan media yang digunakan untuk merekam penggunaan wewenang untuk memberikan otorisasi terlaksananya transaksi dalam organisasi. Prosedur pencatatan yang baik akan menjamin data yang direkam dalam formulir dicatat dalam catatan akuntansi dengan tingkat ketelitian dan keandalannya yang tinggi.

Aktivitas perusahaan PT. Cakrawala Multi Finance Palembang di dalam melakukan pembiayaan dengan cara adanya formulir permohonan agar dapat membantu tim marketing dalam menjalankan tugas dan menjalankan kebijakan prosedur perusahaan. Pelanggan terlebih dahulu menghubungi tim marketing untuk membuat janji pengajuan permohonan pembiayaan. Menyerahkan syarat- 
\begin{tabular}{llr} 
syarat dan & \multicolumn{1}{c}{ mengisi formulir } \\
permohonan & pembiayaan untuk \\
memudahkan & petugas marketing \\
mengetahui & identitas pelanggan.
\end{tabular} Mengarahkan kepada pelanggan pada struktur kredit yang terbaik bagi perusahaan dan calon pelanggan. Menyiapkan kelengkapan dokumendokumen dan data-data yang dibutuhkan untuk melakukan survey. Manajer dengan ketat menerapkan kebijakan uang muka (down payment) untuk menjaring pelanggan secara lebih selektif. Menjalin hubungan baik dengan menerapkan paket intensif menarik bagi toko (store), serta menggelar program-program reward dan loyalty incentive berskala nasional maupun atas inisiatif yang diprakarsai kantor-kantor cabang bagi pelanggan.

PT. Cakrawala Multi Finance Palembang telah menetapkan beberapa tugas dari teller adalah menerima pembayaran angsuran secara tunai dari debitur lalu memasukkan data pembayaran tunai ke dalam sistem dengan benar dan akurat sesuai dengan prosedur yang telah ditentukan. Setiap hari seluruh teller melaporkan dan menyetorkan ke bank, setiap penerimaan uang kertas wajib diperiksa dengan lampu ultraviolet, karena jika terdapat uang palsu menjadi tanggung jawab teller. Dikarenakan terjadi perangkapan tugas antara fungsi administrasi dan keuangan (teller) dengan staff finance, sehingga pekerjaan yang harusnya di lakukan oleh beberapa orang hanya dilakukan satu orang saja. Maka dari itu pimpinan PT. Cakrawala Multi Finance Palembang harus meningkatkan kualitas sistem pengendalian intern yang ada untuk mengatasi permasalahan kesalahan pencatatan transaksi keuangan cash maupun non cash. Pihak perusahaan harus menerapkan sistem otorisasi untuk setiap transaksi yang terjadi sehingga setiap kegiatan yang terjadi dapat dipertanggungjawabkan.

Untuk mengatasi permasalahan yang terjadi, perusahaan menerapkan sistem otorisasi yang akan menjamin dihasilkannya dokumen pembukuan yang dapat dipercaya sehingga akan menjadi masukkan yang dapat dipercaya bagi fungsi akuntansi dan fungsi administrasi. Sehingga dapat memperkecil terjadinya kecurangan yang dilakukan pihak manajemen yang dapat merugikan pihak perusahaan serta menetapkan kebijakan uang muka (down payment) untuk menjaring pelanggan secara lebih selektif.

c) Praktik yang sehat dalam melaksanakan tugas dan fungsi setiap unit organisasi.

Aktivitas yang dilakukan di perusahaan yaitu melakukan pemeriksaan mendadak kepada pegawainya apakah pegawainya bekerja di perusahaan sudah baik dan benar dalam menjalankan tugas dan tanggung jawabnya. Perusahaan juga melakukan penyimpanan formulir di beberapa laci dengan tidak memberikan nomor urut tercetak, sehingga sering terjadinya kehilangan dokumen dan formulir-formulir yang dianggap penting oleh perusahaan.

PT. Cakrawala Multi Finance Palembang praktik yang sehat belum berjalan dengan cukup baik. Hal ini dapat terlihat dari belum adanya dokumen yang bernomor urut tercetak secara permanen yang dapat menyebabkan kelalaian dalam pencatatan, terjadinya kecurangan seperti pencurian maupun tindakan penyelewengan lainnya. Selain itu, hal tersebut juga dapat mengakibatkan kesalahan pencatatan transaksi keuangan di perusahaan. Fungsi administrasi yang bertanggung jawab atas surat pemberitahuan ditulis dalam buku catatan biasa. Selain itu juga 
fungsi administrasi officer juga sering tidak melaksanakan penagihan kepada debitur yang di mana dari kantor seolah-olah melakukan kegiatan penagihan agar mendapatkan uang jalan dan sering tidak menyetorkan hasil tagihan ke kasir tepat pada waktunya.

Untuk mengatasi masalah yang terjadi, pihak perusahaan harus menerapkan dokumen yang bernomor urut tercetak secara permanen sehingga dalam penggunaannya dokumen tersebut dapat dipertanggung jawabkan dan dapat mengurangi tingkat kecurangan yang terjadi pada perusahaan. Apabila terjadi kekeliruan maka dapat diselesaikan dengan baik sesuai dengan peraturan yang berlaku. Penerapan surat pemberitahuan di buat dua lembar satu untuk debitur dan satunya untuk arsip administrasi. Selain itu juga perusahaan harus memberikan teguran berupa sanksi untuk setiap karyawan yang telat menyetorkan hasil tagihannya ke pada perusahaan. Dengan adanya teguran berupa sanksi maka akan mengurangi kecurangan yang terjadi di perusahaan.

d) Karyawan yang mutunya sesuai dengan tanggung jawab mereka.

Bagaimanapun baiknya struktur organisasi, sistem otorisasi dan prosedur pencatatan, serta berbagai cara yang diciptakan untuk mendorong praktik yang sehat, semuanya sangat tergantung pada manusia yang melaksanakannya. Diantara empat unsur pokok pengendalian intern tersebut, unsur mutu karyawan merupakan unsur sistem pengendalian intern yang paling penting. Jika perusahaan memiliki karyawan yang kompeten dan jujur, unsur pengendalian yang lain dapat dikurangi sampai batas yang minimum, dan perusahaan tetap mampu menghasilkan pertanggung jawaban keuangan yang dapat diandalkan. Karyawan yang jujur dan ahli dalam bidang yang menjadi tanggung jawabnya akan dapat melaksanakan pekerjaannya dengan efisien dan efektif, meskipun hanya sedikit unsur sistem pengendalian intern yang mendukungnya.

Di dalam menerima karyawan perusahaan melakukan tes terlebih dahulu. Kemudian tes itu dilakukan beberapa tahap. Sesudah melewati tahap seleksi dan beberapa tes maka ditetapkanlah sebagai karyawan kontrak atau sebagai karyawan tetap.

PT. Cakrawala Multi Finance Palembang telah melakukan prosedur pemilihan karyawan yang cakap dan kompeten di bidangnya. Karyawan yang cakap dan kompeten sangat dibutuhkan di dalam perusahaan. Untuk menyeleksi karyawan yang berkompeten, perusahaan harus melakukan tes agar dapat menemukan karyawan yang jujur dan bertanggung jawab terhadap pekerjaannya. Jika dilaksanakan oleh karyawan yang tidak kompeten dan tidak jujur, maka perusahaan ini akan mengalami kerugian yang sangat besar dalam perusahaan.

\section{3) Analisis Piutang Tak Tertagih / Kredit Macet}

Piutang Tak Tertagih timbul karena adanya resiko piutang yang tidak dapat terbayar oleh debitur perusahaan karena berbagai alasan, misalnya pailit/bangkrut, force major, karakteristik pelanggan, dsb. Semakin banyak piutang dagang yang diberikan maka semakin tinggi tingkat resiko kemungkinan piutang yang tak terbayar.

Kredit bermasalah adalah suatu keadaan dimana pelanggan sudah tidak sanggup membayar sebagian atau seluruh kewajibannya kepada perusahaan seperti yang telah 
diperjanjikan. Piutang tak tertagih dapat dikategorikan sebagai berikut :

\section{$>\quad$ Kredit kurang lancar}

Kredit Kurang Lancar adalah substandard yaitu kualitas kredit yang tingkat pengembaliannya mencerminkan keadaan yang kurang baik karena terdapat tunggakan pembayaran dalam jangka waktu tertentu yang ditetapkan.

Aktivitas yang ada pada PT. Cakrawala Multi Finance Palembang dimana merupakan perusahaan yang bergerak di bidang pembiayaan elektronik untuk semua jenis merk elektronik. Apabila terjadi pembayaran kurang lancar maka tugas $A / R$ Officer yang datang ke rumah untuk mengingatkan debitur segera membayar angusrannya. Adapun tugas A/R Officer adalah bertanggung jawab atas terlaksananya kegiatan penagihan yang ditugaskan kepadanya secara tepat waktu di wilayah tempatnya bekerja.

PT. Cakrawala Multi Finance Palembang pada kredit kurang lancar sering ditemui debitur yang menunggak hingga satu bulan penuh dan kadangkadang tiga bulan tidak memenuhi kewajibannya untuk membayar cicilan elektronik yang telah disepakati sebelum terjadinya perjanjian kredit. Dimana penetapan denda untuk kreditkredit yang kurang lancar sebesar 10\% dari angsuran pembayaran. Sebaiknya perusahaan lebih memperketat didalam pemberian pembiayaan dan mempertegas kebijakan perusahaan terhadap pelanggan.

\section{$>\quad$ Kredit diragukan}

Kredit Diragukan adalah doubtfull loan yaitu kredit yang digolongkan diragukan karena kredit yang bersangkutan tidak memenuhi kriteria lancar dan kredit kurang lancar serta akan mempengaruhi kualitas kolektibilitas kredit, tetapi berdasarkan penilaian.

Aktivitas yang ada pada PT. Cakrawala Multi Finance Palembang dimana merupakan perusahaan yang bergerak di bidang pembiayaan elektronik untuk semua jenis merk elektronik. Apabila terjadi kredit bermasalah maka tugas $A / R$ Officer yang datang ke rumah untuk mengingatkan debitur segera membayar angsurannya. Adapun tugas A/R Officer adalah bertanggung jawab atas terlaksananya kegiatan penagihan atau penarikan terhadap unit kendaraan pelanggan yang menunggak, mengunjungi pelanggan yang menunggak untuk melakukan penagihan atau penarikan unit dan memberikan surat tugas penarikan kepada pelanggan yang menunggak.

Dalam perusahaan PT. Cakrawala Multi Finance Palembang tidak pernah terjadi kredit yang diragukan. Tapi sebaiknya perusahaan lebih mengutamakan pada fungsi evaluasi terhadap pelanggan agar tidak terjadinya kredit diragukan akibat pelanggan menunggak dalam melakukan pembayaran angsuran.

\section{Kredit macet}

Kredit macet atau problem loan adalah kredit yang mengalami kesulitan pelunasan akibat adanya faktor-faktor atau unsur kesengajaan atau karena kondisi di luar kemampuan debitur.

Aktivitas yang ada pada PT. Cakrawala Multi Finance Palembang dimana merupakan perusahaan yang bergerak dibidang pembiayaan elektronik untuk semua jenis merk elektronik. Apabila terjadi kredit bermasalah maka tugas $A / R$ Officer yang datang ke rumah untuk mengingatkan debitur segera membayar angsurannya. Adapun tugas A/R Officer adalah bertanggung jawab atas terlaksananya kegiatan penagihan 
atau penarikan terhadap unit elektronik pelanggan yang menunggak, mengunjungi pelanggan yang menunggak untuk melakukan penagihan atau penarikan unit dan memberikan surat tugas penarikan kepada pelanggan yang menunggak.

Dari tabel diatas menunjukkan bahwa perusahaan mengalami kredit macet dari tahun 2015-2017. Dari data tersebut pada tahun 2016 menunjukkan persentase yang cukup tinggi yaitu sebesar 8,03\%. Maka sebaiknya perusahaan lebih mempertegas di dalam pemberian pembiayaan.

Kredit macet dalam perusahaan PT. Cakrawala Multi Finance Palembang sering terjadi pada pelanggan yang pembayarannya menunggak hingga enam bulan. Penagihan sering di lakukan oleh $A / R$ officer yang bertanggung jawab atas terlaksananya kegiatan penagihan, dan remedial officer yang bertanggung jawab atas terlaksananya kegiatan penagihan atau penarikan terhadap unit elektronik pelanggan yang menunggak. Jika lewat enam bulan pelanggan tidak bisa membayar kewajibannya, tugas remedial officer memberikan surat tugas penarikan elektronik kepada pelanggan. Pelanggan tidak berhak untuk menghalangi tugas remedial officer.

Berdasarkan teori yang ada maka kinerja remedial officer dapat dikatakan penting di dalam perusahaan terhadap berlangsungnya siklus keuangan dalam perusahaan agar tidak mengalami kerugian yang begitu besar nantinya.

Maka sebaiknya untuk menghindari penarikan elektronik akibat pelanggan tidak membayar kewajibannya kepada perusahaan, ada baiknya pelanggan sebelum tanggal jatuh tempo segara membayar kewajibannya kepada perusahaan, guna untuk menghindari hal-hal yang tidak di inginkan.

\section{Kesimpulan dan Saran}

\section{a) Kesimpulan}

Berdasarkan hasil penelitian analisis sistem pengendalian intern piutang dalam meminimalisir piutang tak tertagih pada PT. Cakrawala Multi Finance Palembang. Penulis menarik kesimpulan, yaitu :

1. Kualitas sistem pengendalian intern pada PT. Cakrawala Multi Finance Palembang belum cukup baik karena masih terdapat rangkap tugas antara fungsi administrasi dan keuangan (teller) dengan staff finance yang menjadi penyebab terjadinya kesalahan dalam mencatat transaksi cash maupun non cash.

2. Terjadinya kesalahan pencatatan dalam perusahaan dikarenakan kelemahan sistem pengendalian intern yang ada. Dimana kelalaian petugas teller dalam proses pencatatan transaksi cash maupun non cash dan belum diterapkannya dokumen dengan nomor urut tercetak secara permanen.

3. PT. Cakrawala Multi Finance Palembang mempunyai jumlah piutang yang cukup besar, sehingga dalam pengendalian terhadap piutang sangat diperlukan, agar piutang tersebut dapat tertagih semaksimal mungkin.

4. Perusahaan melakukan penetapan denda sebesar 10\% agar dapat menekan tingkat besarnya kredit kurang lancar yang dialami diperusahaan.

\section{b) Saran}

Berdasarkan kesimpulan yang telah dikemukakan, penulis memberikan saran-saran perbaikan yang mungkin dapat digunakan 
sebagai dasar pertimbangan bagi pihak perusahaan PT. Cakrawala Multi Finance Palembang untuk meperbaiki sistem pengendalian intern persediaan yang ada.

1. Sebaiknya perusahaan menambah atau merekrut karyawan baru untuk ditempatkan di bagian administrasi, keuangan (teller), dan staff finance sehingga tidak terjadinya perangkapan tugas di bagian unit tersebut.

2. Sebaiknya sistem wewenang otorisasi dan prosedur pencatatan yang dilakukan harus sesuai dengan fungsi dan tanggung jawab masing-masing karyawan sehingga setiap kegiatan yang terjadi dapat dipertanggungjawabkan.

3. Praktik yang sehat dalam melaksanakan tugas dan fungsi setiap unit organisasi seharusnya dilakukan dengan cara menerapkan dokumen dengan nomor urut tercetak secara permanen untuk menjamin tidak terjadinya kecurangan yang ditimbulkan oleh karyawan perusahaan.

4. Sebaiknya perusahaan memberikan denda kurang dari 10\% agar konsumen lebih memilih perusahaan pembiayaan PT. Cakrawala Multi Finance Palembang dari pada perusahaan pembiayaan lainnya.

\section{DAFTAR PUSTAKA}

Andayani, Wuryan, 2008, Audit Internal, Edisi 1, Cetakan Pertama, Penerbit: BPFEYogyakarta: Yogyakarta.

Elder, Rendal J, dkk, 2011, Jasa Audit dan Assurance, Penerbit: Salemba Empat, Jakarta.

Kasmir, 2011, Bank dan Lembaga Keuangan Lainnya, Edisi revisi, Penerbit:

Rajawali Pers: Jakarta

Kuncoro, Mudrajat, 2003, Metode Riset untuk Bisnis \& Ekonomi, Penerbit: Erlangga, Jakarta.

Mulyadi, 2002, Auditing Jilid 2, Penerbit: Salemba Empat, Jakarta.

Mulyadi, 2006, Auditing Jilid 2, Edisi Revisi, Penerbit: Salemba Empat, Jakarta.

Sanusi, Anwar. 2011, Metodeologi Penelitian Bisnis, Penerbit: Salemba Empat, Jakarta.

Sugiyono, 2012, Metode penelitian kuantitatif kualitatif dan $R \& D$, Penerbit: Alfabeta, Bandung 